\title{
DNA のナノスケール構造と電子状態
}

\author{
松本卓也・前田 泰・内藤泰久 \\ 川合知二 \\ 大阪大学産業科学研究所 恶567-0047 大阪府茨木市美穂が丘 8-1
}

(2001 年 12 月 18 日受理)

\section{Nano-scale Structure and Electronic Properties of DNA Molecules}

Takuya Matsumoto, Yasushi Maeda, Yasuhisa NaItoH and Tomoji KawaI

The Institute of Scientific and Industrial Research, Osaka University 8-1 Mihogaoka, Ibaraki, Osaka 567-0047

(Received December 18, 2001)

\begin{abstract}
Non-contact atomic force microscopy (NC-AFM) has been employed to observe double-stranded DNA. Cu(111) surface is found to be useful to realize high-resolution imaging of DNA molecules without the effect of water-layer and to improve the tip shape during the scan for imaging. NC-AFM images reveal the double-helix structure whose averaged repeat distance agrees with Watson-Crick model. However, the observed height of DNA molecules is only $1 \mathrm{~nm}$ that is the half of natural diameter of double-stranded DNA suggesting the strong deformation due to the surface adsorption. The simultaneous measurements of frequency-shift and tunneling current indicate that DNA molecules show tunneling conductivity across the strand with the attenuation factor $\beta=1.1$.
\end{abstract}

\section{1.は じめに}

分子生物学とナノテクノロジーの融合により新しい分 野であるナノバイオロジーが生まれつつある。光の起爆 剂となったのは，原子間力顕微鏡（Atomic Force Microscopy, AFM) である。AFM の多種多樣な測定モードを用 いて, DNA, 蛋白, 酵素など, 生体中で働く巨大分子 の形態や分子間相互作用を単一分子レベルで調べること ができる。先行して発明された走査トンネル顕微鏡と比 べると, AFM 測定では, 試料に電気伝導性が必要ない ので, 生体分子や巨大分子測定に適しているが, 分解能 では大きく劣るという欠点があった ${ }^{1}$ 。しかし, 非接触 原子間力顕微鏡 (Non-contact Atomic Force Microscopy, NC-AFM) が 1995 年に発明され, 原子・分子分解能が 達成されて状況は一変した。最近では, 半導体清浄表 面 ${ }^{2 \sim 4)}$ のみならず, 金属酸化物 ${ }^{5)}$, 絶縁性イオン結晶6), ポルフィリン単一分子7), 自己組織化膜帛など, 樣々な

E-mail: matsumoto@sanken.osaka-u.ac.jp
系で高分解能画像が報告されている。本論文では，NCAFM を用いて DNA 分子の高分解能測定を行った結果 について述べる。DNA 分子は水溶性であるので, 固体 表面上に展開するには, 電解質水溶液から試料を作成す る必要がある。また, DNAの構造はかさ高いので, 探 針先端の形が分子画像の分解能に大きな影響を及ぼす。 これらは生体分子測定で共通して要求される条件である ので, DNA の高分解能測定技術を確立しておけば，光 の技術は広い範囲に適用可能であると考えられる。

$$
\text { 2. 実験 }
$$

NC-AFM 測定には, 試料導入室, 試料処理室, 試料 作製室, SPM 測定室の 4 つのチャンバーから構成され た差動排気システムを用いた。SPM 測定室の背圧は $1 \times$ $10^{-10}$ Torr である。SPM ステージおよびスキャンコント ロールは日本電子製のものを使用した。周波数シフトの 検出には, 独自に開発した水晶振動子制御スーパーへテ ロダイン位相同期ループを用いた (Fig. 1)。この回路は， $0.1 \mathrm{~Hz}$ の周波数分解能をもち, $\mathrm{kHz}$ オーダーの広い範囲 


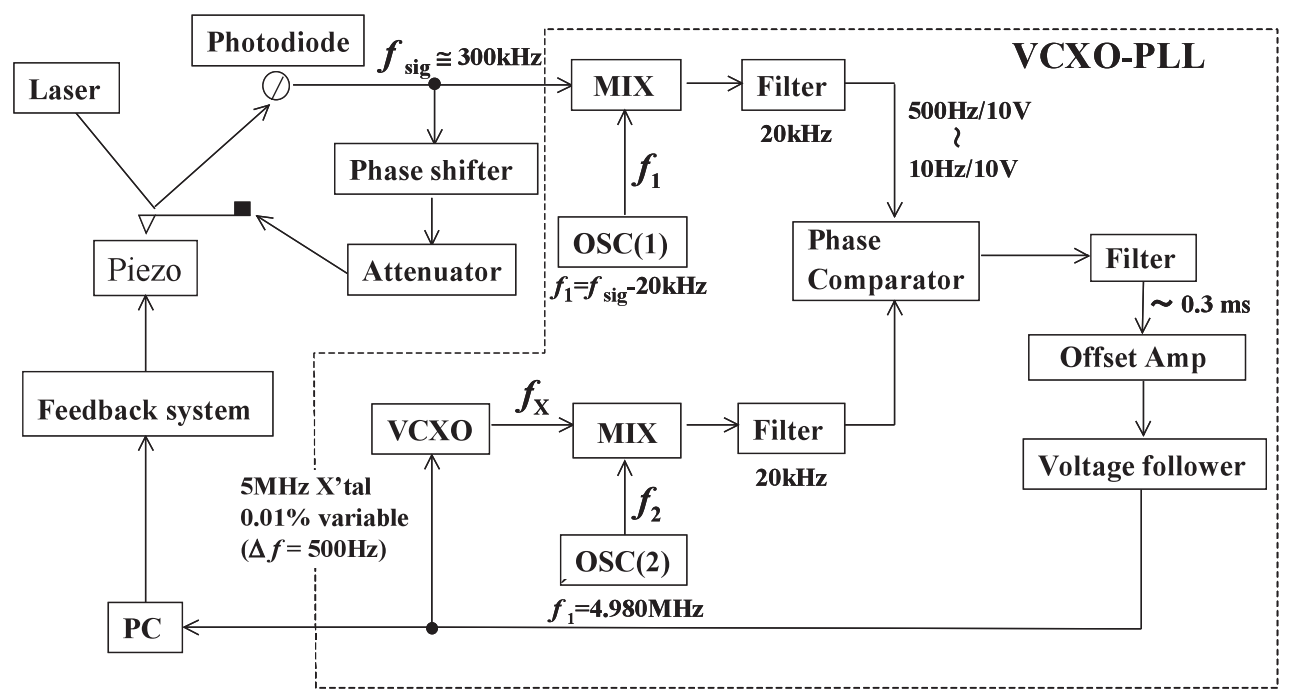

Fig. 1 Block diagram of crystal-controlled super-heterodyne phase-locked loop system for frequency shift detection in non-contact atomic force microscopy.

の周波数シフトに追従可能である。とくに，後述するよ うに水溶液を扱う生体分子試料では, 吸着水の影響で強 い力が動くので , 探針を試料にアプローチするときには 数 $\mathrm{kHz}$ におよう周波数シフトに対応する必要がある。

また , 大気中タッピングモード (TM-AFM) 測定には セイコー電子製の装置を利用した。

試料は二重鎖 DNA である pBlueScript II KS ( - ) (STRATEGENE，2961 塩基対)を用いた。基板には， マグネシウムイオン処理を行ったマイカ基板とマイカ上 に成長した $\mathrm{Cu}(111)$ 薄膜基板を用いた。マイカ基板上 における測定では, DNA 純水溶液を濃度 $10 \mu \mathrm{g} / \mathrm{ml}$ に調 製して $1 \mu \mathrm{l}$ を滴下し, 数分待ったのち, 液滴をブロワ 一で吹き飛ばした。基板に $\mathrm{Cu}(111)$ を用いた場合は， DNA 純水溶液を $5 \mu \mathrm{g} / \mathrm{ml}$ に調製し, パルスバルブから 真空中に噴霧して DNA を吸着した9"。

大気中 TM-AFM 測定では, 材質が $\mathrm{Si}$ の長方形カンチ レバーで, バネ定数が $15 \mathrm{~N} / \mathrm{m}$, 共振周波数 $135 \mathrm{kHz}$ の ものを用いた。一方, 真空中 NC-AFM 測定では, B ド ープされた低抵抗 Si の長方形カンチレバーで, バネ定 数が $30 \mathrm{~N} / \mathrm{m}$, 共振周波数 $300 \mathrm{kHz}$ のものを使用した。 このとき,チップ先端のアスペクト比を改善するために， $0.1 \sim 1 \mu \mathrm{N}$ の力で探針を $\mathrm{Cu}(111)$ 表面に押し当て, 探針 表面の $\mathrm{SiO}_{2}$ 層を除去し, 弚の後, $\mathrm{STM}$ フィードバック 状態で $5 \sim 10 \mathrm{~V}$ の電圧を数分間印加して探針先端に針状 突起を形成したものを使用した。

\section{3. 結果と考察}

\section{1 マイカ基板上の DNA 観察}

Fig. 2 は TM-AFM と NC-AFM 測定の結果を比較した ものである ${ }^{10)}$ 。TM-AFM 像を見ると，DNA 鎖が 1 本の 部分と 2 本が絡まった部分は, コントラストの差として 明瞭に識別できる。しかし，この絡まった部分は，特徵 のない明るい線として観察されているに過ぎず，DNA 鎖が絡まりあっている樣子はわからない。これに対して， NC-AFM 像では, 2 本の DNA 鎖が絡まりあう樣子もは つきりと見てとることができる。また，キンク周辺では 二重らせん構造が弛緩した樣子も観察される。

以上の例のように,一般に,NC-AFM を用いれば,TMAFM よりも高い分解能が容易に実現される。この分解 能の差異は大気と真空という環境の違いで試料が影響を 受けたものではない。後に詳述するが, ママイカ基板上の 吸着水は真空中においても, 室温では大気中とほぼ同じ 状況にある。高分解能が実現されるのは, NC-AFM は 力の検出感度か極めて高く, 引力領域で非接触測定が可 能であるので, Fig. 3 のように, 探針先端のミニチップ か壊れることなく有効に衝くからであると考えられてい る $^{11)}$ 。

しかし, DNA のような生体分子系では, このミニチ ップの能力も十分には発揮されにくい。例えばDNAの 二重らせん周期 (約 $3.4 \mathrm{~nm}$ ) の観測もなかなか実現し なかった。光の理由として, $\square 1 \mathrm{DNA}$ 試料を水溶液から

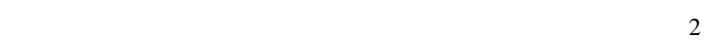



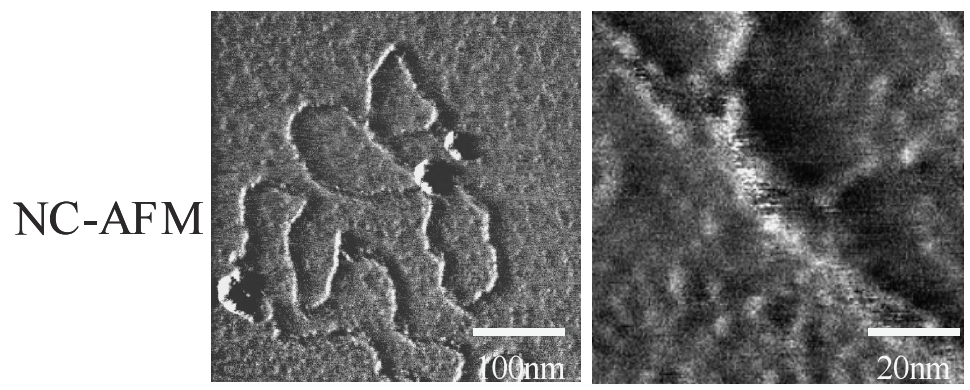

Two DNA c rossing

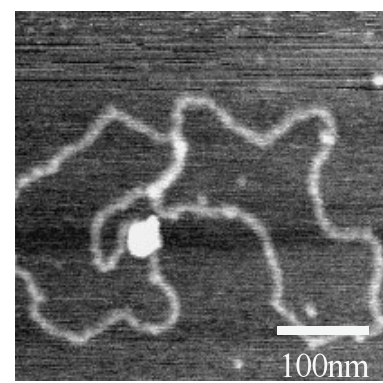

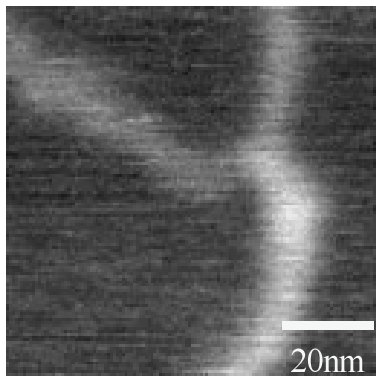

Two DNA c rossing

Fig. 2 Image difference of double-stranded DNA molecules between tapping and non-contact mode atomic force microscopy. In the non-contact AFM images, the feature of tangled strands and relaxed helix can be observed.

\section{(a) NC-AFM}

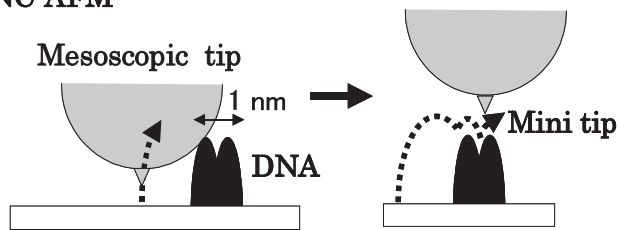

Detailed structure

(b) TM-AFM

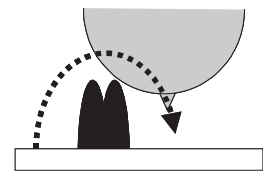

Fig. 3 Schematic illustrations of the effect of mini-tip. Because of high sensitivity of non-contact mode operation, the mini-tip is able to trace the fine structure without destroying the mini-tip.

かさ張った分子の測定では, チップ先端のアスペクト比 が小さいと，ミニチップが有効に働かない，などが考え られる。光こで,これらの要因の解決を図ることにした。

3.2 フォースカーブ測定

DNA を始めとする生体分子の測定に最も一般的に用
いられる基板はマイカである。マイカをへき開すると， 簡単に原子的平坦表面が得られる。この表面は水に強く 大気中で安定であり,生体分子の付着性もよい。しかし， これらの特性は表面が親水的であることを意味してお り，高分解能 AFM 測定において障害となる表面水層を 除くことは容易でない。Fig. 4 に接触モードにおけるフ オースカーブ測定の結果を示す ${ }^{10)}$ 。Fig. 4 (a) はマイカ をへき開後, 速やかに超高真空チャンバーに導入して測 定したフォースカーブである。約 $10 \mathrm{nN}$ の強い吸着力が 観測される。この試料を一昼夜, 超高真空チャンバー内 に放置しても，(b) のように吸着力は全く変化しない。 (c) のように $100^{\circ} \mathrm{C}, 30$ 分間の加熱を超高真空中で行 った後も， $4 \mathrm{nN}$ 程度の吸着力が残っている。

マイカ基板は良い絶縁体であるので, 表面には静電ポ テンシャルが存在する。この静電ポテンシャルは試料の 取り扱いの履歴により変化するが, 超高真空中では, 数 時間で大きく変化することはない。また, カンチレバー を試料に接触させると接触帯電が起こるが, NC-AFM は文字通り非接触で引力領域における測定が可能である ので, この接触帯電を避けて, 試料表面の静電ポテンシ ヤル測定を行うことができる12)。Fig. 5 (a) は導電性チ ップを用いて測定したチップのバイアス電圧とフィード 


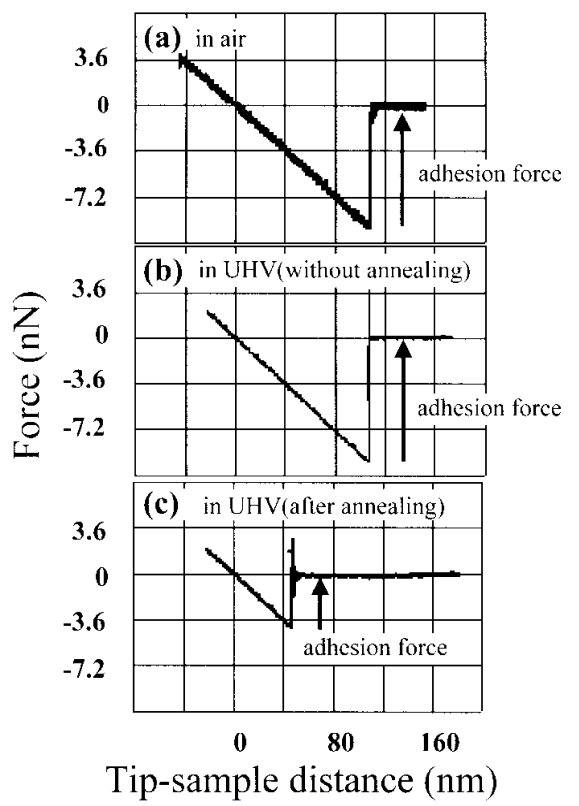

Fig. 4 Force curve measurements for a mica substrate taken by a $\mathrm{SiN}$ cantilever (spring constant is $0.09 \mathrm{~N} / \mathrm{m}$ ). The force curves are for measurements made (a) in air, (b) in a vacuum in which the sample was left overnight, and (c) in a vacuum in which the sample was annealed at $100^{\circ} \mathrm{C}$ for $30 \mathrm{~min}$. Although the adhesion force in air could not be reduced even in a vacuum, it was diminished by annealing in a vacuum.

バック位置との関係である。このとき，周波数シフトの セットポイントは $30 \mathrm{~Hz}$ とした。黑丸は大気中から導入 したマイカ基板, 白丸は超高真空中 $320^{\circ} \mathrm{C} て ゙ 80$ 分間加 熱処理して, 表面の吸着水をできるだけ除去した後のマ イカ基板についての結果である。超高真空中で加熱処理

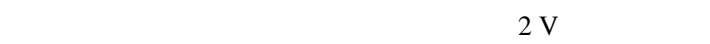
バック位置は明確な極小值を示す。このとき表面ポテン シャルとチップのポテンシャルが等しくなり, 静電気力 は打ち消されている。ところが, 加熱処理をしていない マイカ試料では, フィードバック位置は明確な極小值を 示さず , チップバイアスが-3--5V の範囲でほぼ一定 の値を示す。これは, Fig. 5 (b) のモデル図に示したよ うに，表面吸着水の存在により誘電分極が生じるため， チップにバイアスをかけても静電ポテンシャルは打ち消 されず, 外部電場に応じたほぼ一定の力が㗢くことを示 唆している。このような条件では, 誘電損失が発生する ので, 引力領域の測定であっても, カンチレバーの振動 励起エネルギーか潵逸することを意味している。

この状況を周波数シフトの距離の関数として示したの が Fig. 6 である。大気中から導入しただけで, 加熱処理 (a)

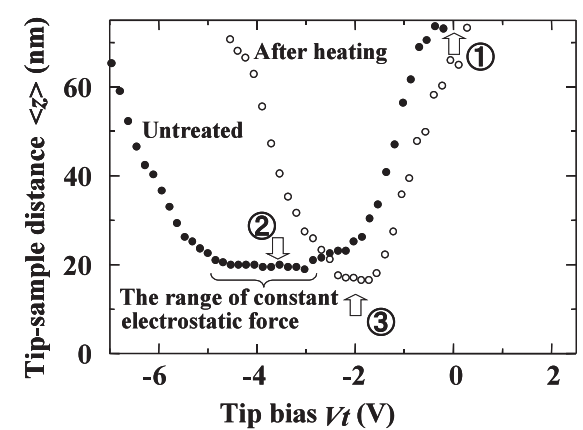

(b)

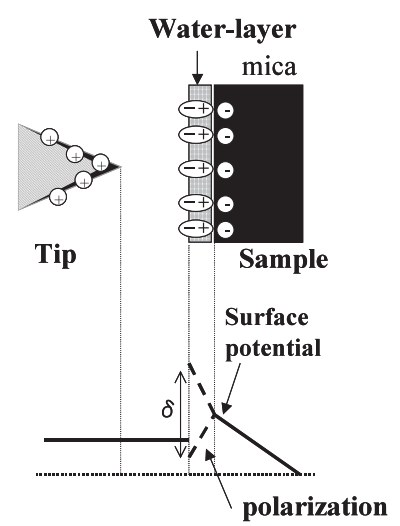

Fig. 5 (a) Relationship between tip bias $V t$ and tip-surface distance $\langle z\rangle$ for untreated mica $(\mathbf{)})$ and dried mica (O) surfaces. The measurements were performed under a closed-feedback setting $\Delta f=30 \mathrm{~Hz}$. (b) Schematic view of the electrostatic potential between the tip and the surfaces of untreated mica.

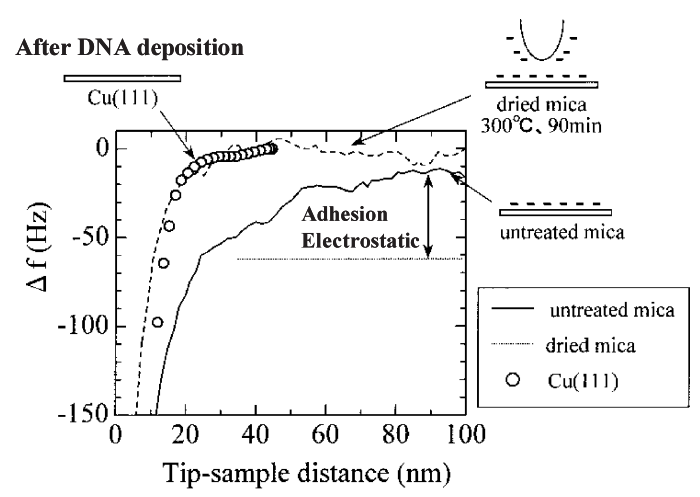

Fig. 6 Variation of frequency shift $\Delta f$ as a function of the tip-surface distance $\langle z\rangle$ for untreated (solid line) and heated (dashed line) mica, and $\mathrm{Cu}(111)$ surface after the exposure to water spray (solid circles). 
していないマイカ基板では, 遠距離から周波数シフトの 低下が見られる (実線)。NC-AFM の高感度・高分解能 は, 周波数シフトの急峻な距離依存性に基づくものであ るので, このような条件では高分解能測定は難しい。こ れに対して, 加熱処理したマイカ基板では周波数シフト の距離依存性が急峻であるので, 高分解能測定が可能で ある。実際，試料を熱処理してDNA の高分解能測定に 成功した例も報告されている ${ }^{13)}$ 。しかし一般に生体由来 分子は熱変性しやすく, 加熱処理は分子観察の方法論と して一般性を持ち得ない。また，Fig. 2で示したように， 温和な加熱条件では表面水を除くことは極めて困難であ る。加熱なしに, 高分解能観察を実現できる方法が必要 である。

$\mathrm{Cu}(111)$ 基板は高真空中で水を吸着しないことが知 られている。この特性を生かし,パルスバルブから DNA 水溶液を真空チャンバー内の $\mathrm{Cu}(111)$ 清浄表面に噴霧 した試料について STM 観察が行われてきた" 法は, 吸着水がないという点で, NC-AFM 測定にも適 している。Fig. 6 に $\mathrm{Cu}(111)$ 表面上に DNA 水溶液を噴 霧した後で測定した周波数シフトの距離依存性データを 示した。加熱処理を一切行っていないにもかかわらず， $\mathrm{Cu}(111)$ の点 (○) は加熱処理したマイカ表面の曲線 (破線) と良く一致する。この結果から, $\mathrm{Cu}(111)$ と真 空噴霧法を利用すれば, 水の問題なしに, 高分解能 AFM による水溶性生体分子観察が可能であることが明らかに なった。

$3.3 \mathrm{Cu}(111)$ 表面上 DNA $の$ 高分解能観察

$\mathrm{Cu}(111)$ 面の利用はチップの形状制御という点でも 有利である。一般にDNA など生体分子はかさ高い。NC$\mathrm{AFM}$ 測定では試料とチップ間距離が STM よりも近いの で, チップ先端周辺のアスペクト比が分解能に及ぼす影 響は深刻である。絶縁体の試料やチップを用いた測定で は, チップの状態を測定中に変えるのは極めて難しい。 しかし, 導電性試料と導電性カンチレバーを用いれば， 電界印加による原子移動を利用したアスペクト比の改善 が可能である。Fig. 7 は実験項で示した手順に従い, チ ップ先端のアスペクト比を改善した後で観測した $\mathrm{Cu}$ (111) 表面上の DNA 像である ${ }^{14)}$ 。二重らせん周期に対 応した凹凸がはっきり確認され，探針先鋭化が有効であ ることがわかった。このようにして測定したDNAの二 重らせん周期の分布を示したのが Fig. 7 (b) のヒスト グラムである。3-4 nm に分布の最大值があり，ワトソ ン-クリックモデルの值 $3.4 \mathrm{~nm}$ と良い一致を示す。この ことから，表面吸着状態においても，DNAのらせん周 期は大きく変化しないと結論できる。ただし，観測され た周期は 6-7 nm まで広い分布を伴っているのが溶液中

\section{(a) Period of double-helix structure}

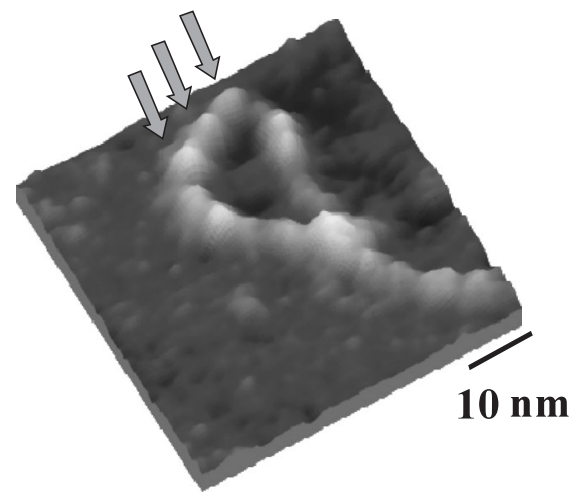

(b)

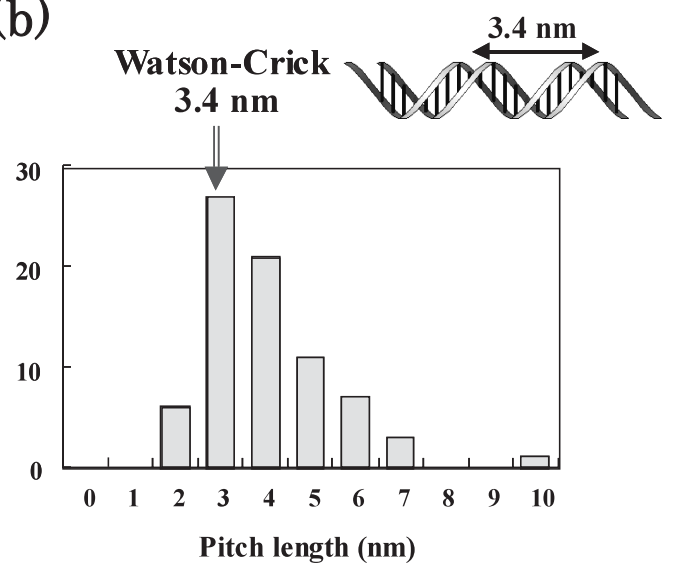

Fig. 7 (a) The result of DNA observation by non-contact atomic force microscopy. The period of double helix structure can be clearly seen. (b) The distribution of the period of double helix structure obtained from the image. The maximum corresponds to the WatsonCrick structure, however, the broad distribution was also observed.

とは異なる。これは, 吸着エネルギーのために, 急な角 度での折れ曲がりやねじれ等の歪をもつたまま DNA 鎖 が固定されるので, 二重らせん構造が局所的に緩んだ結 果と理解できる。

次に DNA 鎖の高さについて検討した。これまで,AFM を用いて表面に吸着した DNA 鎖の高さ計測が行われて きた。しかし，これまでの測定はタッピングモードが用 いられたため, カンチレバーの圧力による DNA 鎖の変 形が常に問題にされてきた。今回の測定は, 非接触モ一 ドによる引力領域で行われたので, 変形の問題を避ける ことができる。結果は， $0.8 \mathrm{~nm}$ 程度の高さが得られた。 Fig. 8 に示したように, 試料一探針間の相互作用が, 引 力から斥力へ遷移する領域での測定や，斥力領域におけ 


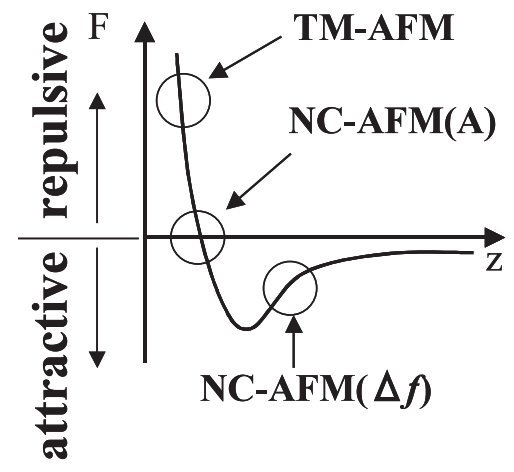

Fig. 8 The set point of non-contact mode with frequencyshift feedback in vacuum, non-contact mode with amplitude feedback in vacuum, and tapping-mode in air.

Table 1 Height values of double-stranded DNA molecules measured by tapping and non-contact mode atomic force microscopy. NC-AFM (A) and NC-AFM $(\Delta f)$ mean amplitude controlled and frequency shift controlled non-contact mode experiment, respectively.

\begin{tabular}{llcc}
\hline \multicolumn{1}{c}{ Mode } & Substrate & Condition & Height $(\mathrm{nm})$ \\
\hline NC-AFM $(\mathrm{A})$ & $\mathrm{Cu}(111)$ & UHV & $0.8-1.0$ \\
NC-AFM $(\Delta f)$ & mica & UHV & 1.0 \\
TM-AFM & mica & in air & 0.8 \\
\hline
\end{tabular}

るタッピングモード測定を比較すると, 力の向き，大き さにかかわらず, 一樣に 0.8-1.0 nm 程度の高さが得ら れた (Table 1)。水溶液中の DNA 分子の直径が $2 \mathrm{~nm}$ で あることを考慮すると, 表面では DNA 分子は扁平な構 造をとっていることが示唆された。また，原子間力顕微 鏡の通常の測定に用いる力では, DNA は変形せず, 十 分に剛直であることもわかった。以上の結果を総合する と, 表面において DNA 分子はワトソンークリックの二 重螺旋構造を維持しつつも, 高さは約 2 分の 1 まで, 扁 平になっていると推測される。

\subsection{NC-AFM/STM 同時測定}

局所表面の電子的性質の研究において, 走査トンネル スペクトロスコピー (Scanning Tunneling Spectroscopy , STS）が大きな役割を果たしてきた。STS を行うと，フ エルミ準位近傍の状態密度分布を調べることができる。 このとき,フェルミ準位付近に特別な状態密度があれば， スペクトル上のピークやショルダーとして観測できる。 有機分子でも, 光合成色素のように, フェルミ準位近傍 にはっきりした電子準位がある場合は STS 測定が有効 である。ところが, 多くの生体関連分子ではフェルミ準 位付近に明確な状態密度は存在しない。フェルミ付近に おける状態密度は, 大部分が金属や半導体など固体表面
のものであり，有機分子に由来する成分は軌道混成によ るわずかな染み出しに過ぎない。このような場合には， スペクトルに特別な特徵は現れない。しかし， $\pi$ 電子を 持つ分子では, 明らかに高い電気伝導性が報告されてい る。このような分子の電子的特性を明らかにするには, 分子から一定距離における状態密度の大小を検討する必 要がある。STS 測定では, 一定トンネル電流でフィード バックをかけるので,スペクトルは規格化されてしまい， 状態密度の大きさを比較検討することはできない。

乥こで, NC-AFM とSTM の同時測定を行い, 表面か らの距離一定の条件における状態密度の比較を試みた。 STM 測定においてトンネル電流 $I$ は, 座標 $(x, y, z)$ における状態密度 $\rho(x, y, z)$, バイアス電圧 $V$, , 関 数として

$$
I \propto V \rho(x, y, z)
$$

で表現される。一方, NC-AFM 測定における周波数シ フト $\Delta f$ は, 探針-試料間のポテンシャル関数を $F(z)$ とすれば，

$$
\Delta f \propto\left(f_{0} / k\right) F^{\prime}(z)
$$

となる。ただし，ここで, $f_{0}$ はカンチレバーの共鳴周波 数, $k$ はカンチレバーのばね定数である。トンネル電流 でフィードバックをかけて走査を行えば， $V$ と $I$ は一定 で $z$ は同時測定なので, 上記二式で共通である。STM と NC-AFM の同時測定を行うという実験操作は, 式の 上では, 上記の二式から $z$ 項を消去する作業と同じ意味 を持つ。したがって $z$ を消去すれば，

$\Delta f \propto F^{\prime}\{\rho(x, y)\}$

の関係式が得られる。この式から，試料-探針間に働く カのポテンシャルの差異がなければ, 周波数シフト $\Delta f$ の值は局所状態密度を反映していることになる。

Fig.9 は (a) DNA 及び (b) EDTA 凝集体 (DNA 水 溶液中に含まれている緩衝溶液の成分) について NC$\mathrm{AFM} / \mathrm{STM}$ 同時測定を行った結果である。EDTA 凝集体 は，原子間力ではきちんと画像化されるが，トンネル電 流では観測されず，ほとんど透明である。これに対して DNA 分子は, 原子間力, トンネル電流ともに明瞭な画 像として現れる。この結果から，DNA 凝集体に比へて , DNA 分子は電子を導きやすいことがわかる。

さらに,この測定結果から DNAの STM 像において 観察される二重らせん周期のコントラストと, DNA 鎖 の凹凸との関係を明らかにすることができる。Fig. 10 に, コントラストメカニズムとして考えられる3つのモ デルを示した。モデル 1 は DNA 鎖の低い部分が明るく， 高い部分が暗くなる場合である。DNA 鎖にほとんど電 流を流す能力がない場合は, 金属基板と接している部分 の軌道混成のほうが, 浮き上がった部分よりも強いので， 


\section{STM topography Frequency shift}

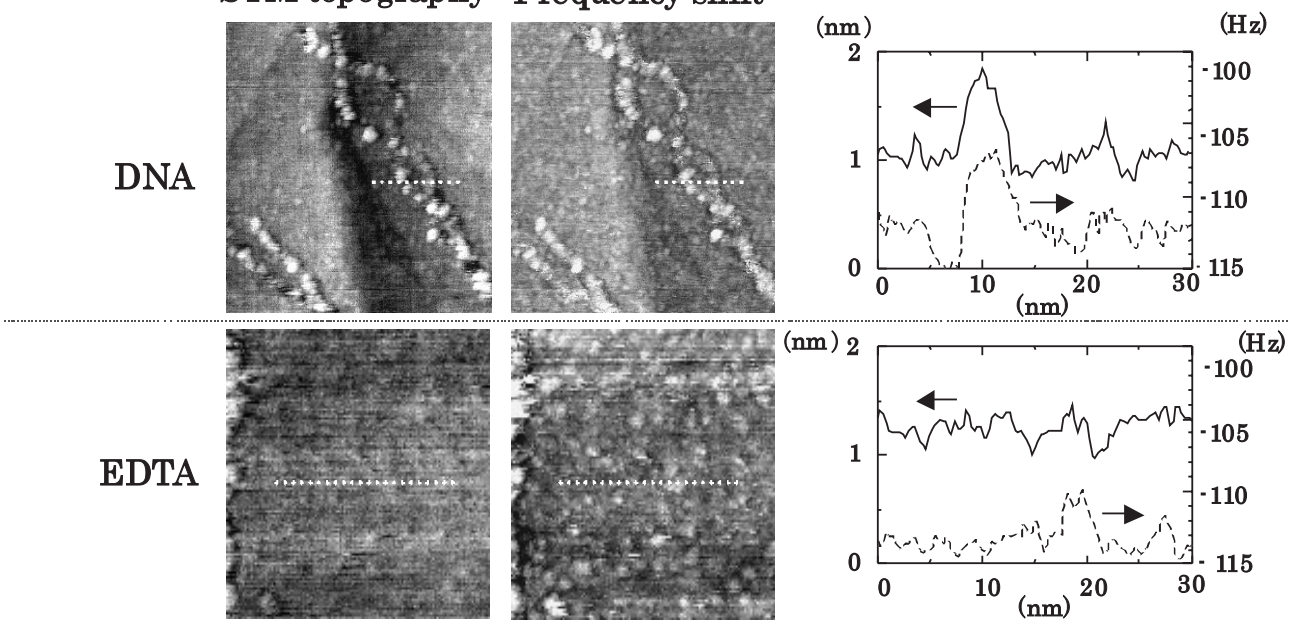

Fig. 9 Simultaneous observation of frequency shift and tunneling current images by multimode non-contact atomic force microscopy. EDTA aggregates (buffer molecules) are observed clearly by force, however, not observed by tunneling current because the those are insulating and don't affect tunneling process from substrate to tip. On the other hand, DNA molecules are imaged clearly by both force and tunneling current. This suggests that there is some contribution of DNA molecules for electric conduction.

\section{STM Contrast Mechanism}

\section{Model 1}

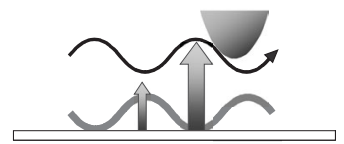

Model 2

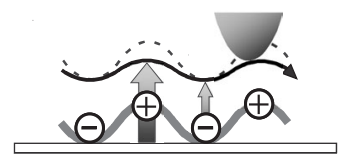

Model 3

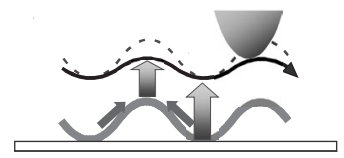

Orbital

Hybridization

\section{Electric \\ Polarization}

\section{Conduction through DNA}

Fig. 10 Possible contrast mechanisms of DNA imaging. Model 1, 2 and 3 represent orbital hybridization, electric polarization, and conduction mechanism, respectively.

STM 像では明るくなると考えられる。しかし，同時測 定の結果，NC-AFM で高い部分が，STM でも高いので， このモデルは直ちに否定される。また，ここで詳細は述 べないが，STM 探針位置に変調をかけて測定したトン ネル障壁像の研究から, 大きな電荷移動は無いことか溉 に明らかになっている。したがってモデル 2 も否定され る。結局，DNA 自身にある程度の電気伝導性があり， DNA 鎖から探針にトンネル電流が流れることを仮定し
たモデル 3 がコントラストメカニズムについて正しい描 像を与えていると考えられる。このモデルに立てば，卜 ンネル抵抗の值から DNA 内における電子波の減衰率 $\beta$ はおよ光 1.1 と見積もることができる。この伝導をバリ スティックなものとするとトンネリングの方向と DNA の $\pi$ スタッキングの方向は直交関係にあるので，電子 の運動量ベクトルの向きを考えると疑問が残る。一方， フェルミ準位近傍に明確な電子準位は存在しないので, DNA 内部で定常的電子輸送が実現されるとする考えも， 矛盾を含んでいる。さらに二重らせん周期の高い部分と 低い部分とでDNA と表面の接触状態がどのように異な るかなど，明確でない部分が多くあり，DNA 分子の電 気伝導に関する物理的描像はまだ明らかではない。

\section{4 . まとめと展望}

DNA に焦点を合わせて，NC-AFM の応用例を述べて きた。これらの結果をまとめたのが Fig. 11 である。表 面吸着状態において,

口1 DNA の二重らせん構造は維持されるものの，吸着 カのために多数のキンクを含んだ形で固定され， 部分的には二重らせんが緩んでいること，

[2 高さは半分程度にまで扁平になっていること，

[3 銅基板と DNA の間で, 大きな電荷移動はないこ と,

[4 DNA の直径方向の電気伝導性は，トンネリングを 仮定すると $\beta=1.1$ 程度である。 


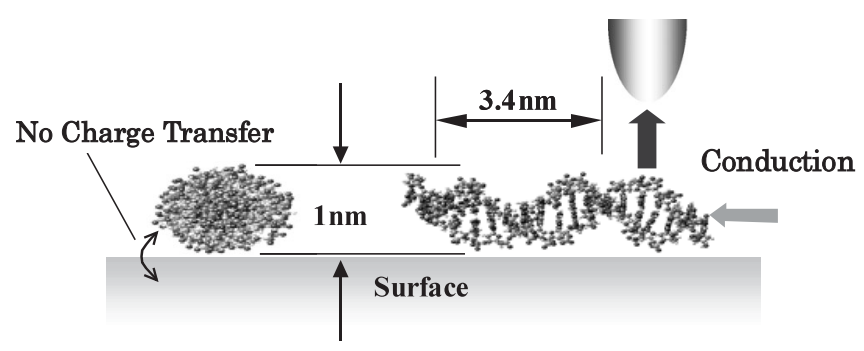

Fig. 11 Schematic illustration of DNA structure on a surface and electric conduction through DNA.

表面上でDNA は扁平であるが , このようなコンフォメ ーションでは, DNA 塩基のスタックは垂直ではなく， 斜めにずれた形になると考えられるので, $\pi$ 電子系を介 した電子輸送にも大きな影響があると考えられる。また， キンクなど局所構造と電気伝導の関係も気になるところ である。

以上示してきたように，NC-AFM はこれまでのTM$\mathrm{AFM}$ に比べて, 遥かに高い分解能で巨大分子・生体分 子を画像化することが可能である。また，NC-AFMの 引力領域における高い感度を利用すれば，トンネル電流 との組み合わせの他にも, ケルビンフォースや化学結合 力をこれまでにない精度・分解能で検出することができ る。生体分子内における, 電荷分布, 電荷移動や化学状 態は極めて重要であるので, 単なる形態観察を超えて, 分子生物学の内容に踏み込んだ研究も可能であると期待 される。さらに, 分子ェレクトロニクス, バイオエレク トロニクスなどナノスケールの回路網の研究では, 導体， 絶縁体を問わず高い分解能で走査しながら電子状態を調 ベることが要求される。現状では NC-AFM は, この要 請に応えることのできるほとんど唯一の計測手段である と言っても過言ではない。NC-AFMの普及とともに , これからナノスケール分子系に関する幅広い研究が展開 されるであろう。

\section{文献}

1) U. Landman, W.D. Luedtke, N.A. Burnham and R.J. Colton: Science 248, 454 (1990).

2) F.J. Giessible: Science 267, 68 (1995).

3) Y. Sugawara, M. Ohta, H. Ueyama and S. Morita: Science 270, 1646 (1995).

4) S. Kitamura and M. Iwatsuki: Jpn. J. Appl. Phys. 35, 668 (1996).

5) K. Fukui, H. Onishi and Y. Iwasawa: Phys. Rev. Lett. 79, 4202 (1997).

6) M. Reichling and C. Barth: Phys. Rev. Lett. 83, 768 (1999).

7) Ch. Loppacher, M. Bammerlin, M. Guggisberg, E. Meyer, H.-J. Guntherodt, R. Luthi, R. Schlittler and J.K. Gimzewski: Appl. Phys. A 72, S 105 (2001).

8) T. Fukuma, K. Kobayashi, T. Horiuchi, H. Yamada and K. Matsushige: Appl. Phys. A 72, S 109 (2001).

9) H. Tanaka, C. Hamai, T. Kanno and T. Kawai: Surf. Sci. 432, L 611 (1999).

10) Y. Maeda, T. Matsumoto and T. Kawai: Appl. Surf. Sci. 140, 400 (1999).

11) T. Matsumoto, Y. Maeda, Y. Naitoh and T. Kawai: J. Vac. Sci. Technol. B 17, 1941 (1999).

12) Y. Naitoh, Y. Maeda, T. Matsumoto and T. Kawai: Surf. Sci. 459, L 446 (2000).

13) T. Uchihashi, M. Tanigawa, M. Ashino, Y. Sugawara, K. Yokoyama, S. Morita and M. Ishikawa: Langmuir 16, 1349 (2000).

14) Y. Maeda, T. Matsumoto, H. Tanaka and T. Kawai: Jpn. J. Appl. Phys. 38, L 1211 (1999). 